\title{
Coccolithophore biomineralization: New questions, new answers
}

Colin Brownlee ${ }^{a *}$, Glen Wheeler ${ }^{a}$ and Alison R Taylor ${ }^{b}$

From the a Marine Biological Association, The Laboratory, Citadel Hill, Plymouth PL1 2PB, UK and ${ }^{b}$ Department of Biology and Marine Biology, University of North Carolina Wilmington, North Carolina 28403, USA

\section{Summary}

Coccolithophores are unicellular phytoplankton that are characterised by the presence intricately formed calcite scales (coccoliths) on their surfaces. Coccolith formation is an entirely intracellular process - crystal growth is confined within a Golgi-derived vesicle. A wide range of coccolith morphologies can be found amongst the different coccolithophore groups. This review discusses the cellular factors that regulate coccolith production, from the roles of organic components, endomembrane organisation and cytoskeleton to the mechanisms of delivery of substrates to the calcifying compartment. New findings are also providing important information on how the delivery of substrates to the calcification site is co-ordinated with the removal of $\mathrm{H}^{+}$that are a bi-product of the calcification reaction. While there appear to be a number of species-specific features of the structural and biochemical components underlying coccolith formation, the fluxes of $\mathrm{Ca}^{2+}$ and $\mathrm{HCO}_{3}^{-}$required to support coccolith formation appear to involve spatially organised recruitment of conserved transport processes. 


\section{Introduction}

Coccolithophores are single celled marine photosynthetic protists belonging to the Haptophyte division of the chromalveolate eukaryotes. They are significant components of the marine phytoplankton with certain species, such as the cosmopolitan Emiliania huxleyi able to form massive blooms in temperate and sub-polar waters. Because of this their ecology, physiology and palaeontology have been well-studied. Coccolithophores also present a paradigm for the study of calcification mechanisms. The ease with which certain species can be cultured, he relative tractability of a unicellular calcification system that produces intricate calcium carbonate structures (coccoliths) allows questions relating to the biological control of crystal formation and morphology to be addressed.

Coccolithophore calcification has received considerable attention in recent years with many studies directed to the potential impacts of ocean acidification - the decrease in ocean $\mathrm{pH}$ associated with the dissolution of anthopogenically-derived $\mathrm{CO}_{2}$ into the surface ocean. While these studies have generally not directly addressed questions relating to better mechanistic understanding of coccolithophore calcification, they have revealed a number of features of coccolithophore biology (e.g. strain variability, plasticity of calcification response, genetic adaptation, species differences) that are pertinent to the calcification mechanism [e.g. 1-3]. Nevertheless, important questions remain to be answered in order to fully elucidate the cellular drivers and regulators of calcification that are essential for understanding the roles of coccolithophores in the ecology of the oceans, predicting responses to changing ocean chemistry and realising the potential of coccolithophores for biotechnological applications.

\section{The essentials of coccolithophore calcification}

Well preserved coccoliths can be found well preserved in sedimentary records $220 \mathrm{Ma}$ and molecular clock studies estimate that the first calcifying haptophytes (calcihaptophytes) 
originated $\sim 330 \mathrm{Ma}$ [4]. This suggests that coccolithophores evolved under ocean carbonate chemistry conditions that were significantly different from those of the present day. Most studies of coccolithophore calcification mechanisms have focussed on the "model" species E. huxleyi which is easily isolated and cultured, with a large body of physiological data derived from culture experiments. These advantages, together with a fully sequenced genome [5] and an array of additional genomic resources have led to significant advances in understanding the biology and physiology of coccolithophores. The calcite coccoliths of diploid E. huxleyi cells are exquisitely sculpted complex multi- crystalline plates that are formed via crystal growth, uniquely, in an intracellular compartment, the coccolith vesicle (CV). Mature coccoliths are secreted to the cell surface where they form an outer coat (coccosphere) (Figure 1). In many species (with the exception of E. huxleyi) the haploid phase produces simpler holococcoliths, formed from rhomohedral crystalline units most likely, in an extracellular space [6]. Nevertheless, the diploid heterococcolith producing life cycle stage represents the diploid calcifying stage that is predominantly found in natural populations and is the dominates production of particulate inorganic carbon in the oceans.

\section{The determinants of coccolith morphology.}

The wide range of coccolith shapes and sizes produced by different species suggests a range of functional roles as well as species-specific cellular factors that determine coccolith morphology. In order to understand the regulation of coccolith morphology it is necessary to understand the cell structures and physiology that are brought into play during coccolith development. Ultrastructural studies of E. huxleyi show the CV to be derived from Golgi cisternae [7]. Coccolith growth proceeds as the CV matures and completed coccoliths are secreted to the cell surface in a single exocytotic event [8]. Coccolith growth begins with the nucleation of calcite crystals with alternating orientations ( $V$ and $R$ units) in a circular arrangement known as the protococcolith ring [7]. The coccolith matures into a distal (upper) shield and outer tube formed of V-units. The lower proximal shield, inner tube and central area elements are derived from R-units. The two unit types alternate with each other 
in a ring on the proximal face of the coccolith and this is interpreted to be the proto-coccolith ring locus, i.e., the location where nucleation occurred. It has been proposed that growth of the protococcolith ring initiates from an organic baseplate of alternating structure that establishes the alternating crystal orientations. In several species this baseplate has been visualised using transmission electron microscopy (TEM) [e.g. 8,9] although its organic composition remains uncharacterised. So far, the only protein known to be intimately associated with coccoliths is the so-called GPA (glutamine, proline, alanine-rich protein) that was initially isolated from a coccolith-associated polysaccharide from E. huxleyi [10]. Subsequently Schroeder et al., [12] identified specific sequences of a non-coding region of the GPA gene that correlated with specific coccolith strain morphotypes ( $A$ and $B$ ) characterised by subtle variations in degree of calcification and coccolith element dimensions. However, the GPA protein does not appear to be directly involved in determining coccolith morphology because transcriptomics studies have shown that the expression of GPA is inversely correlated with the rate of calcification [12]. For example, GPA expression was shown to be higher in non-calcifying haploid cells of E. huxleyi [12] and in diploid cells grown under regimes where calcification was inhibited. It is possible, therefore, that the GPA protein may have a direct role as a negative regulator of calcification. Alternatively, GPA may act as an inhibitor of calcification-related gene expression or the increased levels of GPA transcripts in non-calcifying cells may reflect a translation block of the GPA protein under non-calcifying conditions leading to an accumulation of transcripts. These hypotheses have yet to be tested.

Polysaccharides have also been shown to play a likely key role in the regulation of coccolith formation. A single coccolith-associated polysaccharide isolated from E. huxleyi was shown to prevent calcite precipitation in vitro, leading to the suggestion that the polysaccharide may form an inhibitory barrier regulating calcite crystal growth [13-15]. Pleurochrysis carterae was subsequently shown to produce three types of coccolith-associated acidic polysaccharide (PS-1,2, and 3) [16,17]. One of these, PS-2, was shown to be likely required 
for coccolith nucleation since mutant strains lacking this polysaccharide produced few coccoliths. Cells lacking PS-3, a sulfated galacturonomannan, produced coccoliths that were deficient in calcite [17], suggesting that this was required for coccolith growth and morphology. PS-3 was also shown to localise at the interface between the growing crystal and the membrane of the CV [18]. Moreover, the role of PS-3 was shown to be restricted to the later stages of crystal growth after the protocooccolith ring had been formed. This is consistent with later studies in the related species $P$. haptonemofera [19] showing that PS-1 and PS-3 were surface associated while PS-2 was associated with both the surface and interior of the coccolith, suggesting a role in crystal nucleation or maintenance of coccolith structure. The roles of other intra-crystalline organic components on the control of coccolith nucleation and growth remain to be elucidated. Smith et al [20] extracted a number of protein and polysaccharide components from $P$. carterae coccoliths with potential roles in regulating coccolith growth and morphology. Clearly a large potential array of organic components await characterization from a range of coccolithohore species.

Further controls on coccolith morphology are likely to come from the cytoskeleton and the organisation of the endomembrane system associated with the developing $\mathrm{CV}$. It has been proposed by several workers that cytoskeletal connections with the maturing CV could underpin overall morphology of the coccolith. Indeed studies using inhibitors of actin or tubulin polymerisation have been shown to produce abnormal coccolith morphology [21] though whether this results from inhibition of direct cytoskeletal-CV interactions or indirect effects on Golgi vesicle transport and delivery of substrates to the calcification site (see below) remains to be determined. The role of endomembranes in determining coccolith morphology is also apparent from ultrastructural studies of complex endomembrane anastomosing tubules termed the reticular body closely associated with the CV and likely contiguous with the endoplasmic reticulum in the coccolithophore Scyphosphaera apstenii [10] (Figure 1). Intrusions of the reticular body appear to form membranous "plugs" that contact the organic baseplate, somehow preventing mineralization. These specific ordered 
endomembrane structures were proposed to be critical in the formation of the pattern of central pores of the disk-like coccoliths (muroliths) and the bases of the cup-shaped lapodaliths produced by this species (Figure 1).

\section{Physiology of calcification}

\subsection{Co-ordination of $\mathrm{Ca}^{2+}$ and DIC transport: An issue of compartmentalization?}

How are the pathways for $\mathrm{Ca}^{2+}$ and $\mathrm{DIC}$ organised to prevent unregulated $\mathrm{CaCO}_{3}$ precipitation and to allow co-ordination of inorganic carbon requirements for photosynthesis and calcification? Coccolith crystal growth requires delivery of $\mathrm{Ca}^{2+}$ and dissolved inorganic carbon (DIC) from the external medium to the growing coccolith crystals in the CV. Estimates of $\mathrm{Ca}^{2+}$ influx based on measured rates of calcification in an $E$. huxleyi cell that is calcifying at rate comparable to the rate of organic carbon fixation by photosynthesis indicate that the net trans-cellular flux of $\mathrm{Ca}^{2+}$ is arguably the largest sustained trans-cellular $\mathrm{Ca}^{2+}$ flux of any cell type [22]. This massive net $\mathrm{Ca}^{2+}$ flux poses a number of kinetic and energetic problems for the cell's transport machinery considered in several recent studies. Conventional cellular $\mathrm{Ca}^{2+}$ uptake involves channel-mediated $\mathrm{Ca}^{2+}$ influx across the plasma membrane into the cytosol where it may be transported into endomembrane compartments and organelles such as mitochondria or extruded from the cell by the activities of $\mathrm{Ca}^{2+}$ ATPases and/or $\mathrm{Ca}^{2+} / \mathrm{H}^{+}$antiporters. The requirement to maintain very low cytosolic $\left[\mathrm{Ca}^{2+}\right]$ (around 100nM) in all eukaryotic cells imposes potential severe kinetic constraints on the trans-cytosolic movement of $\mathrm{Ca}^{2+}$ from the inner surface of the plasma membrane to the site of calcification [22,23]. $\mathrm{Ca}^{2+}$ almost certainly diffuses across the coccolithophore plasma membrane into the cytosol down an electrochemical gradient through, as yet unidentified, $\mathrm{Ca}^{2+}$-permeable channels. However, a straightforward entry of $\mathrm{Ca}^{2+}$ into the cytosol across the plasma membrane, followed by diffusion across the cytosol and uphill transport into the coccolith-forming compartment is unlikely [22,24], particularly if this involves a long diffusion path across the cytosol. An alternative or supplement to trans-cytoplasmic $\mathrm{Ca}^{2+}$ diffusion is 
the direct uptake of $\mathrm{Ca}^{2+}$ via plasma membrane vesicle endocytosis, or fluid phase transport that would result in trans-cellular movement of endocytotic vesicles carrying a seawater cargo containing $\sim 10 \mathrm{mM} \mathrm{Ca}^{2+}$. However, studies to date have been unable to demonstrate a fluid phase transport mechanism operating in E. huxleyi or Coccolithus pelagicus [23]. Moreover, a recent modelling study [25] estimated that unfeasible rates of vesicle turnover would be required to accommodate the net $\mathrm{Ca}^{2+}$ flux required for coccolith production if endocytotic vesicles containing $10 \mathrm{mM} \mathrm{Ca}^{2+}$ were the principal delivery route. Similarly, direct pumping of $\mathrm{Ca}^{2+}$ from the cytosol into the $\mathrm{CV}$ [26] via $\mathrm{Ca}^{2+}$-ATPases is unlikely to satisfy the demands of calcification because of the relatively low transport capacity of $\mathrm{Ca}^{2+}$ ATPases would require an unfeasibly high number of transporters on the CV membrane to effect the required fluxes [27]. Higher capacity transporters such as $\mathrm{Ca}^{2+} / \mathrm{H}^{+}$exchangers or $\mathrm{Ca}^{2+} / \mathrm{Na}^{+}$exchangers are more likely to transport $\mathrm{Ca}^{2+}$ into an endomembrane precursor $\mathrm{CV}$ compartment, particularly if the path length for $\mathrm{Ca}^{2+}$ across the cytosol was kept to a minimum [27]. Supporting this hypothesis, the involvement of $\mathrm{Ca}^{2+} / \mathrm{H}^{+}$exchangers is predicted to be kinetically feasible in the modelling study of Holz et al., [25]. In this respect the cortical endoplasmic reticulum could potentially play a role as the primary recipient of $\mathrm{Ca}^{2+}$ entering the cell across the plasma membrane. In this scenario the action of $\mathrm{V}$-type $\mathrm{H}^{+}$ATPases maintains $\mathrm{H}^{+}$electrochemical gradients (inside acidic) in endomembrane compartments, including Golgi-derived compartments. $\mathrm{Ca}^{2+}$ accumulation into an acidic endomembrane compartment via $\mathrm{Ca}^{2+} / \mathrm{H}^{+}$exchangers could occur prior to the biomineralization step. Progressive alkalinization of this $\mathrm{Ca}^{2+}$-charged compartment, possibly resulting from down-regulation of V-type $\mathrm{H}^{+}$ATPase activity would occur as the compartment matures [27], ultimately delivering a high capacity $\mathrm{Ca}^{2+}$ source to the $\mathrm{CV}$ at appropriate $\mathrm{pH}$ for calcification. Gene expression studies support the involvement of $\mathrm{Ca}^{2+} / \mathrm{H}^{+}$transporters at some stage in the accumulation of $\mathrm{Ca}^{2+}$ into the CV or CV precursor compartment $[12,28]$. The putative $\mathrm{Ca}^{2+} / \mathrm{H}^{+}$exchanger $\mathrm{CAX} 3$, but not CAX4 was shown to be up-regulated in calcifying diploid E. huxleyi compared with haploid non-calcifying cells and showed a relation 
with the rate of calcification when this was manipulated in different calcifying diploid strains. This suggested that CAX 3 may play a role in calcification-related $\mathrm{Ca}^{2+}$ transport while the role of CAX 4 may be more related to general $\mathrm{Ca}^{2+}$ homeostasis. Further support for a role of an endomembrane transport pathway for $\mathrm{Ca}^{2+}$ comes from ultrastructural studies showing association of ER tubules providing a large membrane surface area in close proximity to the CV (Figure 1) $[8,9,29]$.

The accumulation of $\mathrm{Ca}^{2+}$ into precursor compartment(s) that is subsequently delivered to the site of calcification in the $\mathrm{CV}$ is consistent with other models of calcification where it has been shown that $\mathrm{CaCO}_{3}$ formation as amorphous calcium carbonate (ACC) occurs prior to calcite crystallization. Delivery of ACC to the calcification site by vesicle transport in has been shown in sea urchin spicules and a range of other systems and is likely to be a widespread mechanism [30-32]. In this way $\mathrm{Ca}^{2+}$ can be transported to the calcification site in a highly concentrated form, allowing vesicle delivery of $\mathrm{Ca}^{2+}$ at rates necessary to sustain calcification. This raises the key question of whether ACC is involved in the calcification process in coccolithophores. To date no evidence has been provided for the existence of ACC in coccolithophores. However, vesicles containing tiny granules $(25 \mathrm{~nm})$ termed coccolithosomes with high $\mathrm{Ca}^{2+}$ content have been demonstrated in EM studies of in Hymenomonas carteri and Pleurochrysis carterae. [16,33]. These have been shown to fuse with the rim of the CV $[16,34]$. The possibility exists that coccolithosomes represent a highly concentrated form of $\mathrm{Ca}^{2+}$ such as ACC. However, Van der Wal et al., [33] showed that while Gogi-derived vesicles containing coccolithosomes fused with CV precursor vesicles, the coccolithosomes disappeared at the onset of calcification. This suggests that either the coccolithosomes were only involved in the early stages of coccolith formation or that the full complement of coccolithosomes required for complete coccolith formation is present from the outset. In invertebrate systems such as the developing sea urchin spicule, a complete structure comprising ACC is first laid down followed by a transition to crystalline $\mathrm{CaCO}_{3}[30$ - 
32]. It has also been proposed that this occurs in a non-aqueous, solid phase environment. In electron microscopy studies to date, however, coccolithophore crystal growth appears to occur without any obvious pre-ACC phase, even at the earliest stages of protococcolith ring formation.

The extracellular source of DIC for calcification in E. huxleyi has been shown in a number of studies to be $\mathrm{HCO}_{3}{ }^{-}$whereas $\mathrm{CO}_{2}$ is utilized directly for photosynthesis under $\mathrm{CO}_{2}$ replete conditions [35-39]. Whether coccolithophores possess a chloroplast-based CCM that allows the accumulation of $\mathrm{HCO}_{3}{ }^{-}$via the action of chloroplast carbonic anhydrase $(\mathrm{CA})$ is not clear. However, a number of studies have indicated that coccolithophores may utilise external $\mathrm{HCO}_{3}{ }^{-}$for photosynthesis at limiting $\mathrm{CO}_{2}$ concentrations, especially at high light 37,39]. Since only $\mathrm{HCO}_{3}{ }^{-}$can be utilised for calcification the assumption is that cytosolic conversion of $\mathrm{HCO}_{3}{ }^{-}$to $\mathrm{CO}_{2}$ is low. On the basis of a detailed modelling study Holz et al [40] proposed that under conditions of high DIC demand (high light and low $\mathrm{CO}_{2}$ ) the conversion of $\mathrm{CO}_{2}$ within the cytosol would not represent an energy-efficient mechanism. Rather, an alternative pathway whereby $\mathrm{HCO}_{3}{ }^{-}$may be taken up directly by the chloroplast may operate under these circumstances. The above argument, along with other experimental observations $[39,41-44]$ indicate that both photosynthesis and calcification may draw on a common cytosolic $\mathrm{HCO}_{3}{ }^{-}$pool to supply their requirements. How this pool is maintained has not been elucidated, although gene expression studies have pointed to a putative anion transporter (SLC-4) that is specific to diploid calcifying cells of $E$. huxleyi [45,12]. Most likely this operates as a $\mathrm{HCO}_{3}{ }^{-} / \mathrm{Cl}^{-}$antiporter at the plasma membrane [12]. The transporters operating to deliver $\mathrm{HCO}_{3}{ }^{-}$to the $\mathrm{CV}$ or precursor compartment have yet to be identified.

4.2. Dicing with deatH ${ }^{+}$? The use of $\mathrm{HCO}_{3}{ }^{-}$as the $\mathrm{DIC}$ external source for calcification results in the intracellular production of $\mathrm{H}+$ in a $1: 1$ molar ratio with $\mathrm{CaCO}_{3}$ precipitation (Figure 2). Miultifactorial experiments [e.g. 38,39] have shown convincingly that E. huxleyi 
calcification rates with were dependent on external $\mathrm{HCO}_{3}{ }^{-}$and independent of $\mathrm{CO}_{3}{ }^{2-}$. Assuming that $\mathrm{H}^{+}$production occurs at, or close to, the site of $\mathrm{CaCO}_{3}$ precipitation, $\mathrm{H}^{+}$will need to be removed from the CV and ultimately the cytosol to prevent acidosis and cell death. Hypotheses have been proposed around the potential use of this supply of $\mathrm{H}^{+}$for $\mathrm{CO}_{2}$ generation in the cytosol but experimental evidence listed above does not support this hypothesis. $\mathrm{H}+$ removed from the $\mathrm{CV}$ or precursor membrane compartments involved in $\mathrm{Ca}^{2+}$ accumulation through the activity of $\mathrm{Ca}^{2+} / \mathrm{H}^{+}$antiporters operating with a stoichiometry of at least $2 \mathrm{H}^{+}: 1 \mathrm{Ca}^{2+}$ can potentially be recycled into the endomembrane compartment through the activity of $\mathrm{V}-\mathrm{H}^{+}$ATPAses (Figure 2) [12]. The finding that coccolithophores possess voltage-regulated $\mathrm{H}^{+}$channels in their plasma membrane that activate upon cytosolic acidification and/or plasma membrane potential depolarization provides a mechanism whereby rapid and high capacity $\mathrm{H}^{+}$efflux from the cell can be mediated (Taylor et al, 2011). The presence of plasma membrane $\mathrm{H}+$ channels is consistent with observations that intracellular $\mathrm{pH}$ is strongly influenced by changes in external $\mathrm{pH}$ (Taylor et al; Suffrian et al). This in turn is consistent with the evolution of a $\mathrm{pH}$ regulatory mechanism that relies on fairly constant external seawater $\mathrm{pH}$ for its effective operation. Recent studies have shown that coccolithophores, along with diatoms and likely other marine protists, have electrically excitable plasma membranes, able to generate plasma membrane depolarizations that are identical to action potentials of metazoan nerve and muscle $[46,47]$. These provide a potentially very effective mechanism for control of voltage-regulated $\mathrm{H}^{+}$ channel activity and intracellular $\mathrm{pH}$ homeostasis.

\section{Concluding remarks: Do all coccolithophores calcify by the same mechanism?}

All calcifying coccolithophores have the ability to calcify in an intracellular Golgi-derived vesicle, suggesting the existence of common underlying mechanisms. The basic machinery of calcification appears to be conserved across the heterococcolith producing 
coccolithophores, for example the recruitment pathways and mechanisms that are conserved across the eukaryotes for transport of $\mathrm{Ca}^{2+}, \mathrm{HCO}_{3}^{-}$and $\mathrm{H}^{+}$. However certain caveats need to be considered when extrapolating mechanistic information obtained largely from a single model species, E. huxleyi.

A number of examples illustrate this. Firstly, as described above, different coccolithophore species appear to produce different polysaccharides associated with calcification. Secondly, a study of carbon isotope fractionation in two different coccolithophore species, Gephyrocapsa oceanica, a close relative of E. huxleyi and Coccolithus pelagicus ssp. braarudii revealed some intriguing differences in their isotope fractionation properties in relation to DIC supply [48]. The authors proposed that $C$. braarudii may utilise $\mathrm{H}^{+}$produced from the intracellular production of $\mathrm{CO}_{3}{ }^{2-}$ from $\mathrm{HCO}_{3}{ }^{-}$for $\mathrm{CO}_{2}$ production for photosynthesis through the action of cytosolic carbonic anhydrase. In contrast, they proposed that the smaller cells of $\mathrm{G}$. oceanica may utilise $\mathrm{H}^{+}$removed from the cell to facilitate external $\mathrm{CO}_{2}$ generation for photosynthesis through the action of external carbonic anhydrase. Note that both of these possibilities contrast with the conclusions from experiments with $E$. huxleyi in which calcification was inhibited by removal of external $\mathrm{Ca}^{2+}[41,42]$ that indicated no mechanistic dependence of calcification on photosynthesis in that species. Thirdly, the GPA gene, proposed to be involved in the regulation of coccolith morphology does not appear in the transcriptomes of coccolithophores other than E. huxleyi and G. oceanica. Given the likely fundamental role of the GPA protein in regulation of coccolith growth and morphology, it seems likely that the organic regulatory components may vary considerably among coccolithophore species. Finally, ultrastructural studies reveal subtle differences in the organisation of the endomembranes involved in calcification. Coccolithosomes, for example have only been observed in two species to date. Further work is clearly needed reveal the variety of mechanistic specializations that give rise to the current array of coccolith morphologies.

\section{Acknowledgements}


Supported by the Natural Environment Research Council and the Biotechnology and Biological Sciences Research Council (CB and GLW). ART acknowledges NSF grant IOS 0949744 and the University of North Carolina Wilmington Microscopy Facility

\section{References}

1. Raven JA (2011) Rokitta S, Rost B (2012) Effects of Co2 and their modulation by light in the life cycle stages of the coccolithophore Emiliania huxleyi. Limnol Oceaogr. 57, 607-618

2. Schluter L, Lohbeck KT, Gutowska M, Groger JP, Riebesell U, Reusch T (2014) Adaptation of a globally important coccolithopiore to ocean warming and acidification. Nat Clim Change 4, 2014-1030.

3. Bach LT, Riebesell, Gutowska M, Federwisch, Shult KG (2015) A unifying concept of coccolithophore sensitivity to changing carbonate chemistry embedded in an ecological framework. Prog, Oceanogr. 135, 125-138

4. Liu H, Aris-Brosou S, Probert I, de Vargas C (2010) A time line of the environmental genetics of the haptophytes. Mol Biol Evol 27: 161-176

5. Read BA, Kegel J, Klute MJ, Kuo A, Lefebvre SC, Maumus F, Mayer C, Miller J, Monier A, Salamov A, Young J, Aguilar M, Claverie JM, Frickenhaus S, Gonzalez K, Herman EK, Lin YC, Napier J, Ogata H, Sarno AF, Shmutz J, Schroeder D, de Vargas C, Verret F, von Dassow P, Valentin K, Van de Peer Y, Wheeler G, Dacks JB, Delwiche CF, Dyhrman ST, Glockner G, John U, Richards T, Worden AZ, Zhang XY, Grigoriev IV, Emiliania Huxleyi A (2013) Pan genome of the phytoplankton Emiliania underpins its global distribution. Nature 499, 209-213

6. Young, JR, Davis SA, Brown PR, Mann S (1999) Coccolith ultrastructure and biomineralization J Struct Biol 126, 195-215.

7. Young JR, Henriksen K (2003) Biomineralization within vesicles: The calcite of coccoliths. In PM Dove, JJ DeYoreo, S Weiner, eds, Biomineralization, Vol 54, pp $189-215$ 
8. Taylor AR, Russell MA, Harper GM, Collins TT, Brownlee C (2007) Dynamics of formation and secretion of heterococcoliths by Coccolithus pelagicus ssp. Braarudii. Eur J Phycol. 42, 125 - 136.

9. Drescher B, Dillaman RM, Taylor AR (2012) Calcification in the coccolithophore Schyphosphera apsteinii (Prymnesiophycae).J Phycol 48,1343-1361

10. Corstjens PLAM, van der Kooij A, Linschooten C, Brouwers G-J, Westbroek, P, deVrind-de Jong EW (1998) GPA, a calcium-binding protein in the coccoliithophorid Emiliania huxleyi (Prymnesiophytceae). J Phycol 34, 622-630.

11. Schroeder DC, Biggi GF, Hall M, Davy J, Martinez JM, Richardson AJ, Malin G, Wilson WH (2005) A genetic marker to separate Emiliania huxleyi (Prymnesiophyceae) morphotypes. J Phycol 4, 874-879

12. Mackinder L, Wheeler G, Schroeder D, von Dassow P, Riebesell U, Brownlee C (2011) Expression of biomineralization-related ion transport genes in Emiliania huxleyi. Envir Microbiol 13, 3250-3265

13. Borman AH, de Jong EW, Huizinga M, Kok DJ, Westbroek P, Bosch L. 1982. The role in $\mathrm{CaCO}_{3}$ crystallization of an acid $\mathrm{Ca} 2+$-binding polysaccharide associated with coccoliths of Emiliania huxleyi. Eur J Biochem 129,179-183.

14. de Jong EW, Bosch L, Westbroek P. 1976. Isolation and characterization of a $\mathrm{Ca}^{2+}-$ binding polysaccharide associated with coccoliths of Emiliania huxleyi (Lohmann) Kamptner. Eur J Biochem 70,611-621.

15. Henriksen K, Stipp SLS (2009) Controlling biomineralization: The effect of solution composition on coccolith polysaccharide functionality. Crystal Growth Design 9, 2088-2097

16. Marsh ME, 1994. Polyanion-mediated mineralization — assembly and reorganization of acidic polysaccharides in the Golgi system of a coccolithophorid alga during mineral deposition. Protoplasma 177,108-122.

17. Marsh, M, Dickinson D. 1997. Polyanion-mediated mineralization - mineralization in coccolithophore (Pleurochrysis carterae) variants which do not express PS2, the 
most abundant and acidic mineral-associated polyanion in wild-type cells. Protoplasma 199, 9-17.

18. Marsh ME, Ridall AL, Azadi P, Duke PJ. 2002. Galacturonomannan and Golgiderived membrane linked to growth and shaping of biogenic calcite. Journal of Structural Biology 139:39-45.

19. Hirokawa Y, Matsuzuka S, Itayama S, Uchida T, Fujiwara S, Ozaki N, Nagasawa H, Tsuzuki M (2012) Laocalization and associative strength of acid polysaccharides in coccoliths of Pleurochrysis haptonemofera (Haptophyta) predicted from their extractability from partially decalcifies coccoliths. Open J Mar Sci 3, 48-54.

20. Smith BL, Paloczi GT, Hansma PK, Levine RP (200) Discerning nature's mechanism for maaking complex biocomposite crystals. J Cryst. Growth 211, 116-121.

21. Langer G, de Nooijer LJ, Oetjen K (2010) On the Role of the Cytoskeleton in Coccolith Morphogenesis: The Effect of Cytoskeleton Inhibitors1. J Phycol 46, 12521256

22. Brownlee C, Taylor, AR (2005) Calcification in coccolithophiores: a cellular perspective. In Coccolithophores: From Molecular Processes to Global Impact (eds H. Thierstein and J. Young) Springer, Berlin, pp. 31-50.

23. Raven JA., 1980. Nutrient transport in microalgae. Adv Microb Physiol 21,47-226.

24. Berry L, Taylor AR, Lucken U, Ryan KP, Brownlee C (2002) Calcification and inorganic carbon acquisition in coccolithophores. Func Plant Biol 29, 289-299

25. Holz LA, Thoms S, Langer G, Wokf-Gladrow D (2013) Substrate supply for calcite precipitation in Emiliania huxleyi: Assessment of different model approaches. $\mathrm{J}$ Phycol 49, 417-426

26. Araki Y, González EL. 1998. V- and P-type $\mathrm{Ca}^{2+}$ stimulated ATPases in a calcifying strain of Pleurochrysis sp. (Haptophyceae). Journal of Phycology 34,79-88.

27. Mackinder L, Wheeler G, Schroeder D, Riebesell U, Brownlee C (2010) Molecular mechanisms underlying calcification in coccolithophores. Geomicrobiol J 27, 585-595 
28. von Dassow P, Ogata H, Probert I, Winker P, Da Silva C, Audic S, Claverie J-M, deVargas C 2009 Transcriptome analysis of functional differentiation between haploid and diploid cells of Emiliania huxleyi, a globally significant photosynthetic calcifying cell. Genome Biol. 10, R114

29. Westbroek P, Dejong EW, Vanderwal P, Borman AH, Devrind JPM, Kok D, Debruijn WC, Parker SB (1984) Mechanism of calcification in the marine alga Emilianiahuxleyi. Phil Trans RoySoc Lond B 304, 435-444

30. Addadi L, Weiner S (2014) Biomineralization: mineral formation by organisms. Phys Scr 89, 098033.

31. Addadi L, Raz S, Weiner S (2003) Taking advantage of disorder: Amorphous calcium carbonate and its role in biomineralization. Adv. Meter 15, 959-970.

32. Addadi L, Joester D, Nudelman F, Weiner S (2006) Mollusk shell formation: A source of new concepts for understanding biomineralization processes. Chem Eur J 12, 980987.

33. van der Wal, P, de Jong EW, Westbroek P, de Bruijn W.C. Mulderstapel AA. 1983b. Polysaccharide localization, coccolith formation, and golgi dynamics in the coccolithophorid Hymenomonas carterae. J of Ultrastruct Res 85,139-158.

34. Outka DE, Williams DC. 1971. Sequential coccolith morphogenesis in Hymenomonas carterae. J Euk Microbiol 18, 285-297.

35. Nimer NA, Iglesias-Rodriguez MD, Merrett MJ. 1997. Bicarbonate utilization by marine phytoplankton species. J Phycol 33: 625-631.

36. Paasche E. 1964. A tracer study of the inorganic carbon uptake during coccolith formation and photosynthesis in the coccolithophorid Coccolithus huxleyi. Physiol Plant 3(suppl):1-82.

37. Kottmeier dm, Rokitta SD, Tortell PD, Rost B (2014) Strong shift from $\mathrm{HCO}_{3}{ }^{-}$to $\mathrm{CO} 2$ uptake in Emiliania huxleyi with acidification: New approach unravels acclimation from short term pH effects. Photosynth Res 121. 265-275 
38. Buitenhuis E, de Baar H, Veldhuis M. 1999. Photosynthesis and calcification by Emiliania huxleyi (Prymnesiophyceae) as a function of inorganic carbon species. J Phycol 35:949-959.

39. Bach LT, Mackinder LCM, Schulz KG, Wheeler G, Schroeder DC, Brownlee C, Riebesell U (2013) Dissecting the impact of $\mathrm{CO} 2$ and $\mathrm{pH}$ on the mechanisms of photosynthesis and calcification in the coccolithophore Emiliania huxleyi. New Phytol $199,121-134$

40. Holz L-M, Wolf Gladrow D, Thoms S (2015) Numerical cell model investigating cellular carbon fluxes in Emiliania huxleyi. J Theor Biol 364, 305-315.

41. Herfort L, Thake B, Roberts J. 2002. Acquisition and use of bicarbonate by Emiliania huxleyi. New Phytol 156,427-436.

42. Trimborn S, Langer G, Rost B 2007. Effect of varying calcium concentrations and light intensities on calcification and photosynthesis in Emilinia huxleyi. Limnology and. Oceanogr 5, 2285-2293

43. Leornados N, Read B, Thake B, Young J. 2009. No mechanistic dependence of photosynthesis on calcification in the coccolithophorid Emiliania huxleyi (Haptophyta). J. Phycol 45,1046-1051.

44. von Dassow P, Ogata H, Probert I, Winker P, Da Silva C, Audic S, Claverie J-M, deVargas C 2009 Transcriptome analysis of functional differentiation between haploid and diploid cells of Emiliania huxleyi, a globally significant photosynthetic calcifying cell. Genome Biol. 10, R114

45. Taylor AR, Chrachri A, Wheeler G, Goddard H, Brownlee C (2011) A Voltage-gated $\mathrm{H}+$ channel underlying $\mathrm{pH}$ homeostasis in calcifying coccolithophores. Plos Biol 9

46. Taylor AR, Brownlee C. 2003. A Novel $\mathrm{Cl}^{-}$inward-rectifying current in the plasma membrane of the calcifying marine phytoplankton Coccolithus pelagicus. Plant Physiology 131:1391-1400.

47. Taylor AR, Brownlee C, Wheeler GL (2012) Proton channels in algae: reasons to be excited. Trends Plant Sci 17, 675-684 
48. Rickaby REM, Hendericks J, Young JN (2010) Perturbing phytoplankton: response and isotopic fractionation with changing carbonate chemistry in two coccolithophore species. Clim Past 6, 771-785.

\section{Figure Legends}

Figure 1. (A-D) SEM images of examples of the four groups of calcihaptophytes. (E) Detail of placoliths from $S$. apstenii (B). (F) TEM section through a coccolith vesicle (CV) of $S$. apsenii showing associated endoplasmic reticulum (ER) layers surrounding the vesicle, the CV- associated reticular body (RB) and inter- and intracrystalline organic matrix (OM). (G) Ordered association of reticular body projections $\left(^{*}\right)$ with a base plate scale of $S$. apstenii reflecting the pattern of distribution of pores in the central region of the mature coccolith (see text for details). Scale bar $10 \mathrm{~mm}$ in $(A, B) ; 3 \mathrm{~mm}$ in $(C, D), 1 \mathrm{~mm}$ in (E,F), 0,25 mm in (G) (EF reproduced with permission from [9].

Figure 2. Hypothetical representation of $\mathrm{Ca}^{2+}$ and $\mathrm{H}+$ pathways associated with coccolithophore calcification (see text for details). Top: Representative cell showing the hypothesized distribution of $\mathrm{V}$-type ATPases and $\mathrm{Ca}^{2+} / \mathrm{H}^{+}$antiporters $(\mathrm{CAX})$ underlying the accumulation of $\mathrm{Ca}^{2+}$ in the $\mathrm{CV}$ precursor endomembranes. CAX-mediated $\mathrm{Ca}^{2+}$ accumulation in precursor Golgi vesicles $(G)$ is driven by V-type $\mathrm{H}^{+}$-ATPase activity and inside acid lumen. Conditions for $\mathrm{CaCO} 3$ precipitation are reached as vesicles mature associated with declining $\mathrm{H}+-$ ATPase activity (right). Alternatively $\mathrm{Ca}^{2+}$ may accumulate in the ER through the activity of CAX transporters (left). Inset (below): $\mathrm{Ca}^{2+}$ may move from the $\mathrm{ER}$ in into the $\mathrm{CV}$ via $\mathrm{Ca}^{2+}$ channels in the $\mathrm{ER}$ membrane and close proximity $\mathrm{CAX}$ transporters in the CV membrane. 


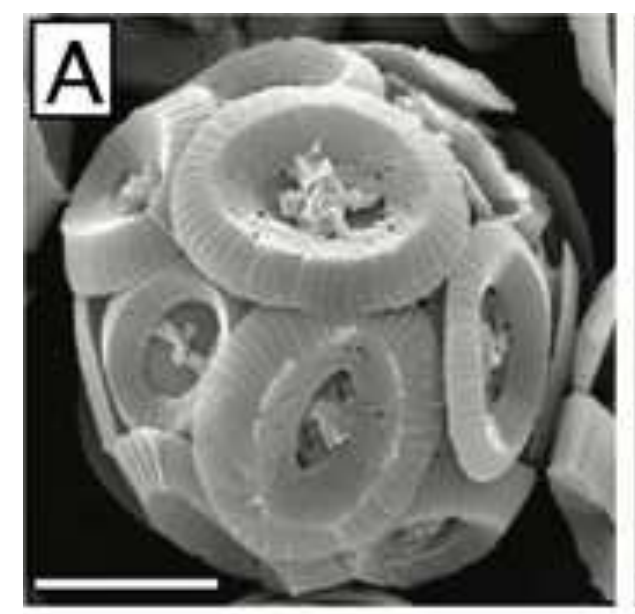

COCCOLITHALES Coccolithus pelagicus ssp braarudii
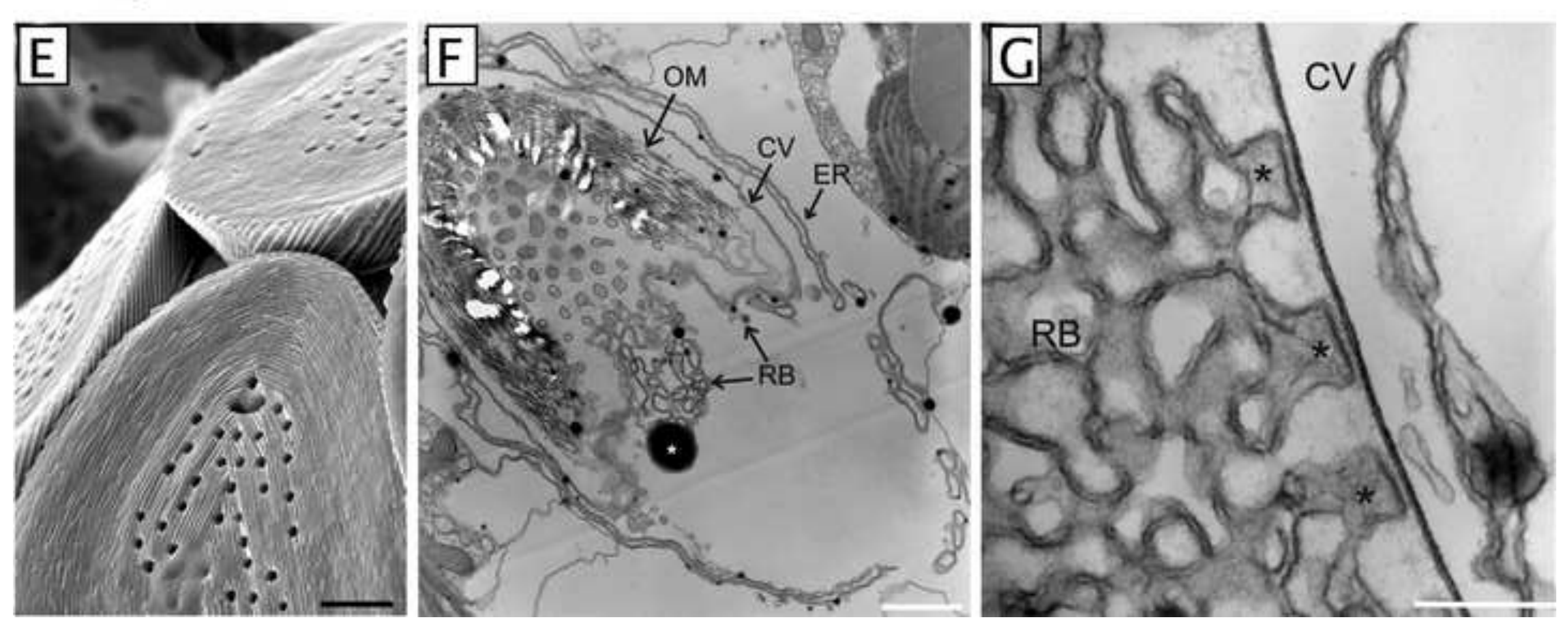

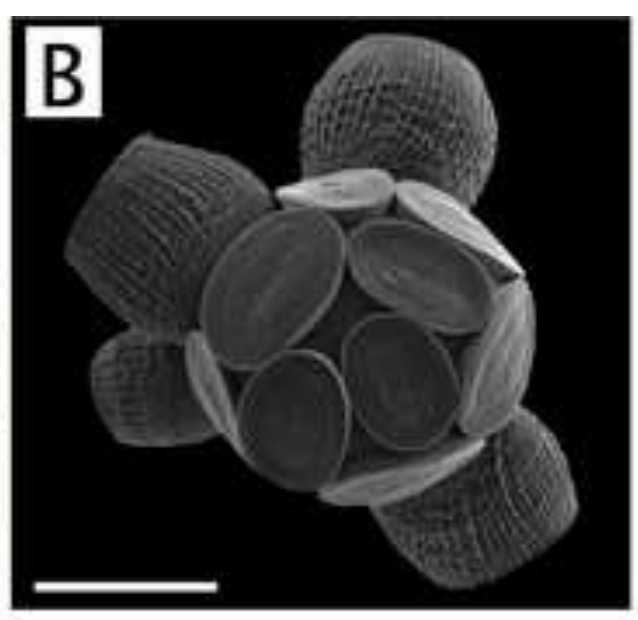

ZYGODISCALES Scyphosphaera apstenii

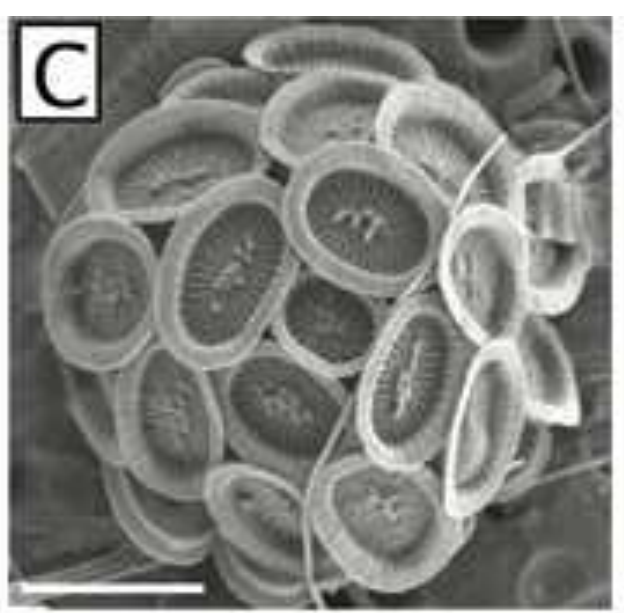

SYRACOSPHAERALES

Syracospheara borealis

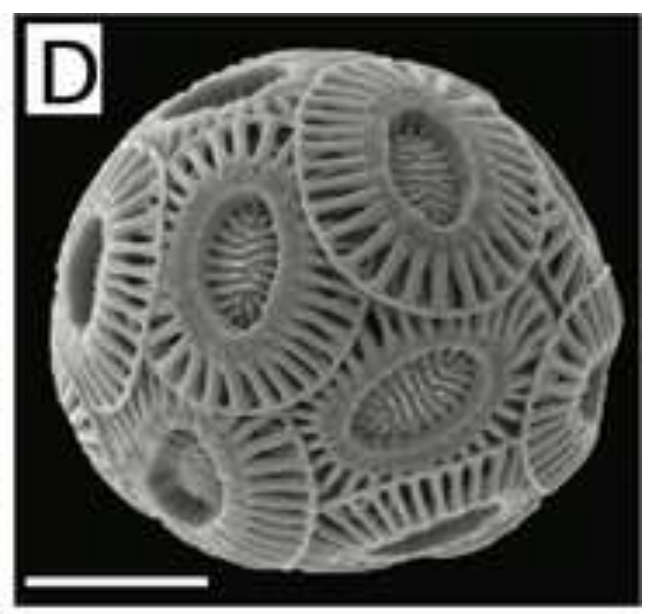

ISOCHRYSIDALES Emiliania huxleyi 

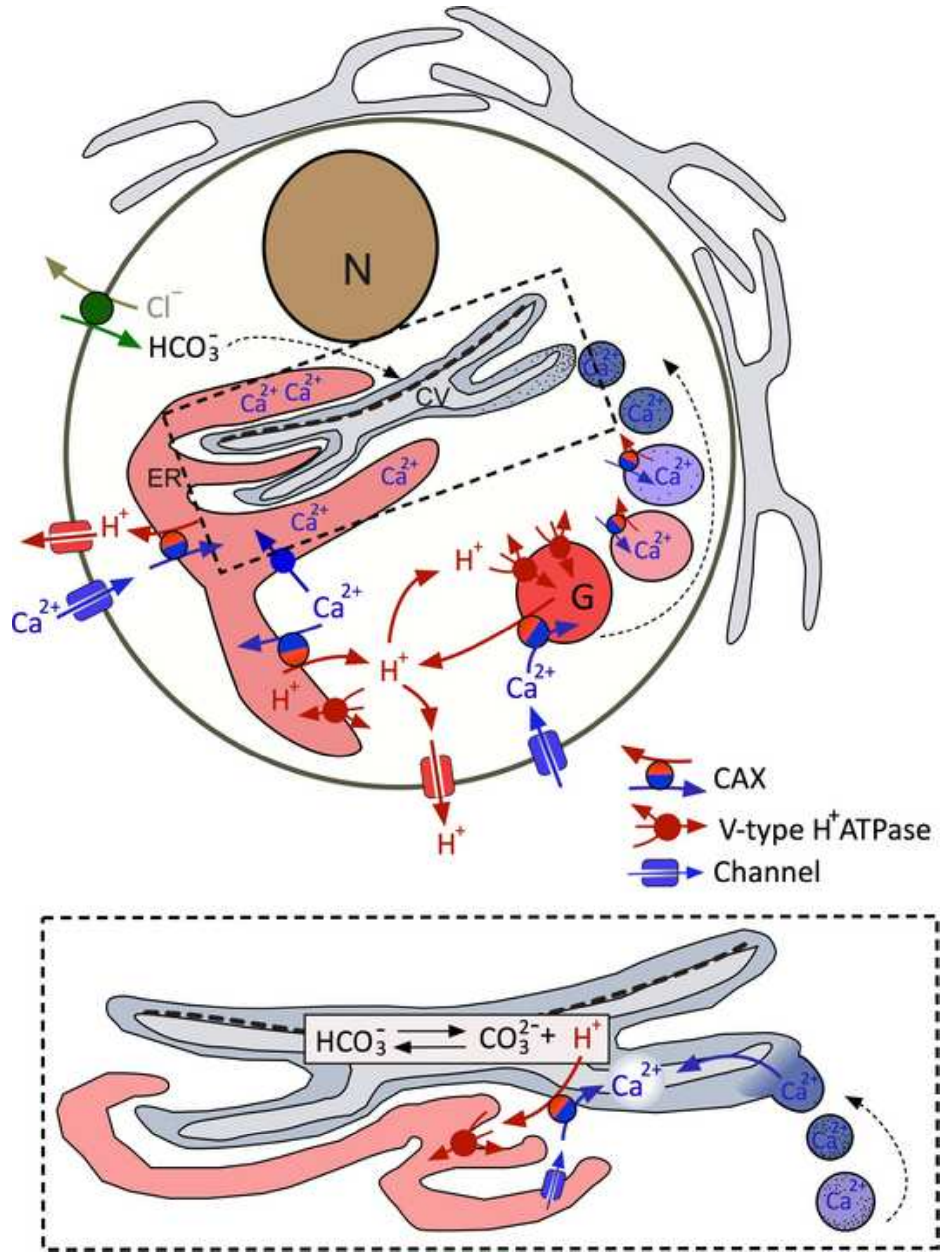